\title{
Pedagogik blir pedagogik och didaktik vid Stockholms universitet
}

\author{
Birgitta Qvarsell
}

This article is primarily based on my experiences as professor of Education during the last years of 1990 and first years of 2000, being appointed professor in 1992 and becoming emerita in 2005. With a background in psychology and a licentiate thesis in this discipline, I had to tackle the question of the relationship between psychology and education in 1969 when I left psychology for education as academic subject. During the period which I overview a number of new positions as professor, appointed as well as promoted, were important as were adjunct professors, recruited to bridge the gap between academy and society at the department. The two main tasks of a university, education and research, came to be in important ways related to a third task - the cooperation with the world outside the academy, We recruited important persons from abroad as doctors of honors, which improved the quality of research as well as the variation of content in courses. My own interest within what I prefer to name Educology concerns primarily childhood culture and the possibility to interpret its importance with the help of theories of socialization and knowledge formation, which in my case have an origin in psychology of perception and philosophy. What has happened at the department from 1969 (starting as a lecturer), via the appointment as professor 1992 and to my retirement 2005 is viewed from my perspective with focus on events that are of importance for my experience. I have taken up some important authors who are not always acting within the discipline of Educology, or even education, but rather important as challengers in a broader sense. I finish my article with a focus on future development, pointing out possibilities to broaden as well as identifying new important challenges, without losing scientific ambitions. 


\section{INLEDNING}

I det här temanumret om pedagogikämnets utveckling vill jag bidra med mina erfarenheter som lärare och forskare, kanske särskilt som professor (utnämnd 1992 och pensionerad 2005) i pedagogik vid Stockholms universitet. Det blir en resumé över hur pedagogikämnet utvecklades och förändrades på 1970och 1990-talet och i början av 2000-talet, bland annat genom tillkomsten av nya professurer och befordringar till professor, samt hur ämnet kom att identifieras eller kanske definieras som vetenskap - såsom det uttrycktes $i$ seminarier och annan verksamhet. Jag tar också lite kort upp hur inordnandet av lärarutbildningen $i$ universitetet och vår institution kom att verka, både vad gäller utbildning och forskning. Att detta med lärarutbildningens inkorporering $\mathrm{i}$ universitetet och dess pedagogik blir lite kort har att göra med min begränsade erfarenhet av vad som hände efter 2009, då lärarutbildningen i Stockholm fördes in under Stockholms universitet.

Det rör sig alltså om pedagogikämnet vid Stockholms universitet, belyst genom etablerandet av flera nya professurer vid min institution under slutet av 1900-talet och början av 2000-talet, och genom annan utveckling och förändring inom universitetet och institutionen. Allt från mitt perspektiv förstås. Eftersom jag i min uppgift som professor och även tidigare kommit att ägna mig särskilt åt forskarutbildning och grundutbildningens forskningsanknytning blir det nog så att dessa förhållanden dominerar i min beskrivning och tolkning av pedagogikämnet.

\section{PEDAGOGIKEN EXPANDERAR OCH UNIVERSITETET FÅR VIDGADE UPPGIFTER}

\section{Problemet med fakultetstillhörighet}

Hösten 1960, då Stockholms högskola blivit Stockholms universitet, tillhörde den pedagogiska institutionen alltämt den humanistiska fakulteten. Ännu fanns ingen samhällsvetenskaplig fakultet i Stockholm. Den tillkom 1964 med ämnena kriminologi, ekonomisk historia, företagsekonomi, kulturgeografi, informationsbehandling, internationell ekonomi, nationalekonomi, pedagogik, internationell pedagogik, psykologi, socialantropologi, sociologi, statistik och statskunskap. Det var dock inte självklart hur uppdelningen i fakulteter skulle se ut. Psykologiska institutionen, min första hemvist vid universitetet, både som studerande och som lärare, ville gärna höra till den naturvetenskapliga fakulteten. Så blev det nu inte, utan både psykologi och pedagogik fördes till samhällsvetenskaperna, men visst hade det på flera sätt varit rimligare att delar av pedagogiken förts till humaniora? Eller varför inte en kulturvetenskaplig fakultet i Stockholm? 
Långt senare, ett stycke in på 2000-talet blev det aktuellt att diskutera pedagogikämnets tillhörighet till en utbildningsvetenskaplig fakultet, men så blev det inte hos oss. Det kan till en del hänga samman med att ämnet pedagogik vid Stockholms universitet tidigare inte hade lärarutbildningen som centralt ändamål. Vår tidigare professor Arne Trankell ville snarare betona påverkansaspekter $\mathrm{i}$ allmänhet, och för egen del ser jag pedagogik som vetenskapen om villkor för människoblivandet, för socialisation och personlig utveckling, snarare än riktad mot utbildningar i specifika former och sammanhang.

I universitetskatalogen 1976/77 visar det sig att de universitetslärare som arbetade vid Lärarhögskolan i Stockholm fanns införda i lärarförteckningen för pedagogiska institutionen vid $\mathrm{SU}$, något som möjligen varslade om den kommande sammanslagningen på 2000-talet. Internationell pedagogik hade en egen institution med vetenskapliga medarbetare som inte stod uppförda på pedagogiska institutionens lista, och därtill gästforskare som stod med amerikanska eller engelska titlar. Detta år var Arne Trankell professor, tjänstledig för forskning med Åke W Edfeldt som vikarie, tillika prefekt. Professor Torsten Husén, som var pedagogiska institutionens förste professor (1953-1956), var nu prefekt vid institutionen för internationell och komparativ pedagogik.

\section{Utveckling och förändringar}

1980-talet innebar för oss en tydlig och markerad forskningsanknytning av grundutbildningen, något som ju också krävdes i de reformer som lanserades. Vi avskaffade studierektorer för grundutbildningen 1986 och lät i stället forskargrupper svara för planläggning och genomförande av grundutbildning liksom forskarutbildning. Till sin hjälp hade de ansvariga professorerna och docenterna dels skicklig administrativ personal, dels en ny typ av amanuensbefattning - studerande som läste magisterutbildningen fick förordnanden på halvtid för att vara behjälpliga vid konstruktion och genomförande av grundutbildningen. Forskargrupperna ordnade sig i forskningsteman som överlevde ganska länge men som kom att successivt avvecklas i och med samordningen med lärarutbildningen som fördes över till Stockholms universitet 2009.

I universitetets katalog 1996, alltså tjugo år senare, har vi tre professorer förtecknade, varav en är adjungerad och därtill två befattningar under tillsättning. Den då enda ordinarie professuren hade jag sedan 1992, och Arvid Löfberg var biträdande professor (senare befordrad enligt den nya befordringsreform som kom i slutet av 1990-talet) och så hade vi en adjungerad professor, Sven Styrborn, som var sociolog och under en period ansvarig för Hälsohögskolan i Stockholm. Under detta år kom också Siv Boalt Boethius (då rektor för Erikastiftelsen och till professionen psykolog) till oss som adjungerad professor. På nittiotalet kom Tom Hagström att knytas till 
institutionen genom en adjungerad professur inom området arbetslivets pedagogik. Bland övriga lärare som finns förtecknade detta år (1996) är många numera docenter och de allra flesta disputerade.

Befattningen som adjungerad professor var omdiskuterad inom den samhällsvetenskapliga fakulteten. Det var viktigt att ändamålet med denna befattning markerades, nämligen att knyta väsentliga företrädare för samhällsliv och arbetsliv, med föreskriven professorskompetens, till universitetets verksamhet, alltså $i$ grunden en kombination av två huvuduppgifter: forskning och samhällsanknytning. Våra adjungerade professorer hade just sådan anknytning som poäng med sin verksamhet på institutionen där de bidrog med både forskning och handledning av forskarstuderande.

\section{Det expansiva nittiotalet}

Man kan säga att nittiotalet hos oss var ett expansivt årtionde, vilket påverkade pedagogikämnets bredd och djup, dess inriktning. När jag tillträdde 1992, efter Åke W Edfeldts pensionering, var jag enda professorn vid institutionen. I slutet av den här perioden (1998) blev tillsättningen av institutionens andra fakultetsfinansierade professur klar genom att Agnieszka Bron tillsattes. Agnieszka kom att bli en viktig person på institutionen, inte minst genom den internationella anknytning hon bidrog med. Jag minns våra besök $\mathrm{i}$ Polen och kanske särskilt hennes beredskap att ge tolkningshjälp för kontakten med en pedagogiskt viktig gestalt inom barnkulturen: Janusz Korczak (se t.ex. Korczak, 1929/1988). Ungefär samtidigt fick befordringsreformen verkan för vår del genom ett antal befordrade professorer i pedagogik: Arvid Löfberg, Inger Wistedt och Ola Halldén. En ny professur med inriktning mot social omsorg och handikappforskning som Anders Gustavsson fick blev en ytterligare förstärkning något år senare. Den professuren hade en knytning till vårt Centrum för kompetensutveckling $\mathrm{i}$ vård och omsorg, liksom Sven Styrborns adjungering.

Nya professorer gjorde att vi kunde utöka våra revir och bedriva pedagogik som vetenskap inom flera områden som $\mathrm{i}$ och för sig redan fanns etablerade genom de lektorer som ju också var docenter och som sökte befordran. Dessa personer hade också undervisning $\mathrm{i}$ sina tjänster vilket gjorde att våra teman kunde breddas, kort sagt: Vi blev flera professorer och flera inriktningar och fick utökat undervisningsåtagande, så för oss var befordringsreformen en klar poäng, då vi ju också hade flera kandidater. Vår tematiska organisation av forskningen och dess anknytning till utbildning på alla nivåer bidrog också till att både forskning och undervisning utvecklades och förändrades, helt $\mathrm{i}$ enlighet med den grundläggande idén om samordning och anknytning mellan både institutionens och annan forskning och institutionens utbildning.

Kraftfullt bidragande till denna utveckling var förstås professorerna, både gamla och nya, men också andra verksamma och aktiva medarbetare: Arvid 
Löfberg för området Arbete, lärande och miljöpedagogik, jag själv för området Barn, ungdom och kultur, Anders Gustavsson för Delaktighet och marginalisering, inom vilket också Ulf Janson tog stort ansvar, vartill kommer områden under tillväxt: Genus (ansvarig Lars Jalmert) och Internationell migration (ansvarig Katrin Goldstein Kyaga), och temaområden av mera generell teoretisk karaktär, som Kommunikation och kunskapsbildning (med Ola Halldén som ansvarig) och Pedagogik och media (Arvid Löfberg och Göran Lange) samt Skola, som fanns som område hos oss, även om vi inte idkade lärarutbildning (ansvarig Lennart Grosin). Området Barn (med olika tillägg) kunde under en period åtnjuta Gunilla Halldéns ledarskap, innan hon lockades över till Linköpings Tema Barn. Per-Johan Ödman som senare blev professor på Lärarhögskolan hade under tiden hos oss ett särskilt ansvar för det pedagogikhistoriska inslaget i forskarutbildningen.

Samtidigt som pedagogikämnet utvecklades och expanderade sitt revir kom universitetets uppgifter att alltmer diskuteras, vidgande för dessa också. De båda centrala uppgifterna utbildning och forskning kompletterades med den så kallade tredje uppgiften (samverkan med samhället utanför akademien) och ibland också en fjärde uppgift: att utveckla universitetet som akademi i sig, vilket innebar förtydligande av universitet som arbetsplats för lärare och annan personal och som studiemiljö för de studerande.

\section{UTVECKLING AV ÄMNET OCH INSTITUTIONEN}

Det var nu inte enbart antalet professorer och professurer som ökade, också andra tjänster tillkom, bland annat lektorat. Däremot minskade antalet adjunkter (utom $i$ lärarutbildningen som ju av tradition har haft adjunktstjänster som sin bas på lärarsidan). Den samhällsvetenskapliga fakultetens strävan var att minska antalet adjunkter och främja de mera forskningsbaserade befattningarna. Jag tillhörde som professor i pedagogik denna fakultet och var dess prodekan en viss period, och deltog i många diskussioner om hur fakulteten och institutionerna kunde främja "den tredje uppgiften". Vid institutionen hade vi återkommande konferenser med sådant innehåll, bland annat om hur vi som ämne och institution kunde utveckla relationen till omvärlden. Det är ju inte särskilt svårt att inse att pedagogiken som både praktik och vetenskap har en uppgift i omvärlden, vilket också flera forskningsprojekt och utvecklingsarbeten under den här perioden vittnar om.

Samtidigt växte programmet Multimedia med inriktning mot både pedagogik och ny teknik fram vid det nystartade centret i Botkyrka med Göran Lange som ledare, under institutionens ansvar. Till detta centrum knöt vi ett seminarium, Pedagogik- och mediaseminariet, som startade en egen skriftserie och anordnade en del konferenser.

I verksamhetsberättelsen för pedagogiska institutionen 2001-2002 framgår att det året varit produktivt när det gäller examination av doktorsavhandlingar, 
vilket förstärker den trend av aktiva studerande och handledare som utmärkt institutionens forskarutbildning de senaste decennierna. Livaktiga seminarier och möten mellan handledare som diskuterat utbildningens viktigaste inslag - avhandlingarna - både tillsammans med andra läsare och med doktoranderna själva, har nog bidragit till den trenden. Handledning är ett tema som också varit återkommande, som fenomen och ibland som problem, både vid institutionen och inom fakulteten.

Vi gav ut informationsskrifter när institutionen fyllde 40 respektive 50 år, alltså 1993 och 2003. Där betonade jag, när vi fyllde 40 år 1993, pedagogikämnets karaktär av både samhällsvetenskap och kulturvetenskap, såsom vi utformat disciplinen, och påpekade samtidigt det knepiga med att försöka definiera ämnet, då det lätt kan leda till begränsningar snarare än till möjligheter, som jag menar att pedagogiken som vetenskap rymmer (Löfberg, Holmberg Dovelius \& Bickham, 1993). Per-Johan Ödman gav i denna skrift en historisk bakgrund till vårt ämne och vår institution, där Arne Trankell får en framträdande plats. När det gäller ämnets karaktär lyfte jag fram frågor om mänskliga livsvillkor $\mathrm{i}$ både formella, informella och icke-formella pedagogiska sammanhang. Det menade jag i det här sammanhanget,1993, och jag ser det alltjämt så. Ämnets möjligheter är viktiga att lyfta fram och jag söker mig gärna till litteratur som betonar sådana möjligheter, både i praktiken och i forskningen.

När vi celebrerade våra 50 år, 2003, kunde jag i motsvarande skrifts förord konstatera att mycket hänt med vår institution sedan 40-årsfirandet, alltså under mellanliggande 10 år. Tillkommande personresurser har förstås bidragit, och nya professorer, adjungerade professorer och hedersdoktorer har varit väsentliga för utvecklingen, vilket Ulf Janson konstaterar när han i denna skrift betecknar institutionen som en "50-åring som hittat hem" (Gustavsson, Qvarsell, Aspán, Westanmo \& Bickham, 2003).

En viktig uppgift för en professor, oavsett ämne, är handledning $i$ forskarutbildningen. Det sägs ju att man lär så länge man har elever, och när det gäller handledning av doktoranders avhandlingsarbeten gäller detta i särskilt hög grad. Jag har lärt mig mycket av att handleda de tjugofem doktorander i pedagogik som jag haft förmånen att bistå i deras våndor och framgångar vid min egen institution, liksom några andra vid andra universitet.

\section{SAMARBETEN MED ANDRA INSTITUTIONER OCH HÖGSKOLOR}

Ett i tidigare skeden aktivt studerandesamarbete manifesterat i Psykologiska föreningen aktiverades vid en jubileumsfest $\mathrm{i}$ mitten av nittiotalet. I den föreningen var ju både pedagoger och psykologer aktiva, eftersom båda grupperna utbildades till psykolog en gång $i$ tiden, när psykologutbildningen började ta fastare form på 1950-talet. 
Vi utvecklade också inriktningar med tonvikt på betydelsen av "perspektiv" genom ett livaktigt perspektivseminarium som åren 1995-2005 drevs gemensamt av psykologiska och pedagogiska institutionen (ansvariga var professorerna Henry Montgomery och Birgitta Qvarsell). Vi publicerade med hjälp av Carlssons bokförlag antologin Perspektiv och förståelse - Att kunna se frän olika ball (Montgomery \& Qvarsell, 2001), vilken speglar aktiva diskussioner i flera grupper och med olika relationer.

Tvåtusentalet inleddes för pedagogikens del vid Stockholms universitet med en konfirmering av våra teman - innehållsligt bestämda områden som användes för att organisera både forskning och undervisning. Temana var under denna tid förankrade i pågående forskning och aktiva forskare, till exempel i Arbetslivspedagogik, Barn och ungdom med kultur, Vård och omsorg, Genus, Skola, Pedagogik och Media.

De här temana kom att spela viss roll för pedagogikens fortsatta utveckling och dess manifesterande $\mathrm{i}$ utbildning och undervisning vid institutionen. Jag återkommer till vad som hände med temana när Lärarutbildningen, genom överordnade beslut, fördes över från den sedan 1956 existerande Lärarhögskolan i Stockholm till Stockholms universitet, successivt och med start 2009.

Länge hade vi tre enheter som på olika sätt samverkade för pedagogikens bästa: Stockholms universitets pedagogiska institution, pedagogiken på Lärarhögskolan samt Internationell pedagogik. Vi hade gemensamma kollegier vad gäller forskning och forskarutbildning, medan grundutbildningen inte samverkade annat än om olika kurser innehållsligt kunde ha skäl att göra det, vilket till exempel gällde Barn och ungdom, som leddes av Bengt-Erik Andersson på Lärarhögskolan och som hade ett centrum för barnforskning knutet till sig. Barnforskningen och barnkulturforskningen stöddes annars främst av en viss samverkan med Centrum för barnkulturforskning, för vilket både tidigare föreståndaren Gunnar Berefelt och senare Karin Helander var kraftfulla ledare och för oss viktiga kollegor i samarbete kring främst barnkultur och estetik i pedagogiken.

Det forskarutbildningskollegium vi hade som enande forum för pedagogikämnet upphörde genom att internationell och komparativ pedagogik kom att infogas i den pedagogiska institutionen vid Stockholms universitet och när lärarutbildningen som helhet fördes över till universitetet 2009. Samarbeten av både formellt och informellt slag förekom mellan medarbetare på de pedagogiska institutionerna helt oavsett lärarutbildningens lokalisering. Viktiga samarbetspartners var för min del Siv Fischbein och Sven Hartman, vilka båda var drivande i sällskapet för Janusz Korczaks levande arv, där jag kom att engagera mig på inbjudan av Siv. 


\section{INTERNATIONELLA RELATIONER}

Vi utvecklade också under denna period (1990-talet och framåt) internationella kontakter, bland annat med Latinamerika, där Concepcion i Chile kom att bli platsen för en forskarutbildning under ledning av den $\mathrm{i}$ Sverige forskarutbildade Abelardo Castro tillsammans med Birgitta Qvarsell, Arvid Löfberg, Anders Gustavsson och Ulf Janson. Vi gjorde årliga besök i Chile under perioden 1993-2005. Ofta besökte vi samtidigt Brasilien och Peru där jag etablerade kontakter med bland annat gatubarnscentra utifrån mitt intresse för marginaliserade barns villkor, i detta fall gatubarn men också barn $i$ andra situationer som kan benämnas marginaliserade.

Genom ett anslag som avsågs främja det internationella utbytet fick vi möjligheter att knyta till oss (t. ex. som hedersdoktorer) intressanta forskare och tänkare både inom Europa och världen för övrigt. På så sätt kom vi att samarbeta i olika former med Christoph Wulf i Berlin och Shirley Brice Heath, då i Stanford.

Våra hedersdoktorer med internationell anknytning var under 1990-talet och framåt Paulo Freire (1921-1997), den tidigt legendariske främjaren av både generativa forskningsansatser och insatser i den praktiska pedagogiken (hedersdoktor 1995), Barney Glaser (f. 1930), Grounded Theory-utvecklaren (1999), Shirley Brice Heath (f 1939), språk- och pedagogikforskare med fokus på barn och unga (2001) och Robert Bogdan (f. 1941), inriktad mot specialpedagogik och kvalitativ forskning (2004). Jag fick förtroendet att promovera Paulo Freire vid en resa till Sao Paulo 1995, eftersom han av sin läkare avråddes från att resa till Stockholm för att promoveras där samma år som han fick hedersdoktoratet. Den resan till Brasilien medförde möjligheter för oss att knyta kontakter med flera forskare i Sao Paulo och i andra delar av Brasilien, till exempel Sobral och Fortaleza.

De här kontakterna medförde både innehållslig utveckling av våra forskningsområden och möjligheter att vistas i andra miljöer för att berika våra egna.

\section{PEDAGOGIK SOM VETENSKAP OCH SOM PRAKTISKT FÄLT}

Alltmer blev det viktigt att - särskilt för mig som ny professor 1992 - försöka mejsla fram vad som var utmärkande för den pedagogiska forskningen och för pedagogik som vetenskap. Utifrån mina egna inriktningar kom mitt fokus att riktas mot vad som kunde kallas (och alltjämt kallas så $\mathrm{i}$ ett internationellt sammanhang) edukologi och dess relationer till andra -logier, så som psykologi, antropologi och sociologi, och med fokus på det edukologiska områdets relation till olika praktikfält. Edukologi som begrepp kommer från engelskans educology där den vetenskapliga pedagogiken får en benämning ungefär som andra logier, så här blir det alltså fråga om edukologi som pedagogisk vetenskap. 
Det har ibland varit ett problem att bestämma, just för pedagogiken, vad som är praktik och vad som är forskning. Enklast kan vara att helt enkelt utgå från att pedagogisk forskning handlar om pedagogiska praktiker, att dessa studeras vetenskapligt, men hos oss i Stockholm har pedagogik främst handlat om något annat, inte enbart eller ens i första hand det lärare gör inom olika stadier av utbildning. Lärarutbildningen sköttes ju av Lärarhögskolan i Stockholm fram till 2008/09.

Jag blev bekant med begreppet edukologi (educology) genom ett par internationella forskare, James Fisher (1996) i USA och James Christensen i Australien, som i och för sig identifierade ett lite annat område, men ändå pekade ut poängen med att markera just det vetenskapliga. Att betona det vetenskapliga i pedagogiken betyder inte att vi bedriver psykologi eller sociologi eller för den delen antropologi, men att vi i pedagogiken som vetenskap identifierar väsentliga villkor för förändringar i människans relation till sin omvärld, vilka villkor som krävs för människoblivandet kanske man kan säga.

För att se och visa hur vi skiljer oss från psykologi, som jag själv kommer från med en gammal licentiatexamen i psykologi vid Stockholms universitet, sociologi (även om området utbildningssociologi ju finns) eller antropologi (som kanske närmast liknar pedagogisk etnografi metodiskt och teoretiskt) har jag alltså använt begreppet edukologi och varit med om att starta en skriftserie hos oss, Lectures in Educology, där tre nummer kom på nittiotalet och början av tvåtusentalet.

Våra edukologiska inriktningar fick också stöd genom de rekryteringar vi under några år gjorde genom att knyta till oss hedersdoktorer. På 1990-talet införde vi också särskilda krav på forskarutbildningens metodinslag och startade en metodinritad skriftserie där inslag som formell datastrukturanalys, pedagogisk etnografi, tolkningsteori, humanvetenskapliga traditioner och grounded theory som fältmetod presenterades och infördes på schemat för doktorander. Exempel på bidrag till skriftserien är Gustavsson (2000) och Qvarsell (1996) som finns upptagna i litteraturförteckningen.

\section{LÄRARUTBILDNINGEN KOMMER IN I STOCKHOLMS UNIVERSITET OCH PÅ INSTITUTIONEN FÖR PEDAGOGIK OCH DIDAKTIK}

Att Lärarhögskolan i Stockholm inordnades i Stockholms universitet sågs på olika sätt av olika aktörer med olika uppgifter. Rubriken för det här avsnittet skulle också kunna vara: Har pedagogiken som vetenskap och praktik ett särskilt akademiskt ansvar för lärarutbildningen? Nej, inte så exklusivt, är jag benägen att svara. Jag tycker inte att pedagogiken som vetenskap, alltså edukologin, har något särskilt ansvar för just lärarutbildningen, även om delar av lärarutbildningen numera befinner sig inom vår (pedagogiska) institution. En del av lärarutbildningen är ju didaktisk, och i det avseendet har vi nog ett 
särskilt ansvar, dock tillsammans med de ämnen som didaktiken avser, alltså undervisningsmetoderna gällande specifika ämnen som ju kan finnas också $i$ skolans övre stadier och i gymnasierna.

Edukologin, den vetenskapliga pedagogiken, har alltså inte exklusivt med utbildning att göra - inte lärarutbildning och inte heller skolans och förskolans undervisande inslag. Med den betoning av pedagogik som studiet av villkor för socialisation och (kunskaps)bildning som jag själv vill göra är det i stället mera generella processer av förändring, både inom och utanför institutionerna, som de forskande pedagogerna, edukologerna, studerar. Då kommer vi in på frågor om demokrati och inflytande, något som vi inte är ensamma om som akademisk disciplin. Ibland kommer vi nära moralfilosofin och stundtals blir det i varje fall metodiskt viktigt att använda etnografi som sätt att närma sig de fält vi studerar och de aspekter vi fokuserar. Sådant har märkts i de kurser jag själv ansvarat för och de seminarier som speglat institutionens forskning.

\section{MINA EGNA FORSKNINGSINTRESSEN OCH TANKETRÅDAR}

\section{Mitt psykologiska forskningsintresse}

Mitt eget forskningsområde har varierat en del under de år jag varit akademiskt verksam. Min licentiatavhandling i psykologi (Qvarsell, 1966) handlar om människors ställningstaganden i konstruerade bedömningssituationer. Den genomfördes inför högertrafikomläggningen (som ju kom 1967) under handledning av Mats Björkman som drev ett inlärningspsykologiskt seminarium vid universitetets psykologiska institution. Min licentiatavhandling i psykologi var en studie av hur säker eller osäker man kan känna sig i trafiksituationer, som här var konstruerade i laboratoriet. Teorier om inlärning (som man kallade det då, alltså inte lärande) blev tillsammans med perceptionspsykologiskt tänkande, bland annat makarna Gibsons affordanceteori som senare utvecklades under 1970-2000-talet (se t. ex. Gibson, 1979; Gibson, 2003), mitt bagage från några år i psykologin. Om dessa år har jag skrivit i en antologi som Lars-Göran Nilsson redigerade som 50-årsskrift för psykologin i Stockholm (Qvarsell, 2003). Att jag fann både nöje och nytta $\mathrm{i}$ att laborera med, pröva och utveckla begrepp som meningserbjudande (affordance) och utvecklingsuppgifter är alltså till viss del psykologins förtjänst - det var där jag deltog i viktiga seminarier inom ramen för licentiatutbildningen i psykologi, med lärare som Mats Björkman, Theodor Kunnapas och Gösta Ekman. 


\section{Pedagogik som vetenskap}

När jag 1969 fick ett lektorat i pedagogik vid Stockholms universitet blev detta en anledning att tänka mera på vad som utmärker pedagogik som vetenskap, jämfört med psykologi som jag ju hade som start i det akademiska livet (förutom sociologi som var det allra första ämne jag läste vid universitetet). Min doktorsavhandling i pedagogik handlar om relationen mellan utvecklingspsykologi och pedagogik (Qvarsell, 1976). Senare har jag kommit att utveckla mitt intresse för barns kultur och pedagogik som studiet av villkor för mänsklig kunskapsbildning och socialisation i olika forskningsuppgifter. Charles Peirce (1990) är en semiotisk pragmatist som haft betydelse för mitt sätt att knyta samman perceptionsteorier av psykologiskt slag med edukologiska forskningsfrågor (se t.ex. Qvarsell, 2000). Ett speciellt intressant samarbete med barnkulturverksamhet handlar om Globträdet, en internationell barnrättsorganisation på svensk botten som startades av entusiaster inom området internationell barnverksamhet, speciellt Kajsa B Dahlström (Qvarsell, 2007). Kajsa och jag har tillsammans presenterat Globträdet vid en barnkulturkonferens på universitetet och sedan skrivit en artikel om det. (Dahlström \& Qvarsell, 2008).

Seminarieverksamheten på pedagogiska institutionen var under en period, vill jag nog påstå, viktigare än kurser. Alla professorer och docenter hade under 1990-talet och däromkring ansvar för forskarseminarier som innebar möjligheter för både lärare och forskarstuderande, ibland också studerande på lägre akademiska nivåer, att lägga fram skisser eller texter över sina arbeten. Själv drev jag under många år seminarier av den karaktären, med start i Utvecklingspsykologiska seminariet som Gertrud Schyl-Bjurman och jag ledde gemensamt parallellt med utvecklingspsykologiska kurser i forskarutbildningen och grundutbildningen från 1970-talets början. Det utvecklades eller övergick till Kulturpedagogiska seminariet i samband med min pensionering 2005 och varade ett tiotal år till 2015, då engagerade deltagare kom att samlas under en nybildning som numera leds av Helen Knutes-Nyqvist på Specialpedagogiska institutionen - vi kallar oss Pedagogiska sällskapet. Kulturpedagogiska seminariet var livaktigt och resulterade i olika slag av skrifter, bland annat en antologi, utgiven av Daidalos förlag, om etiska problem i forskning om och med barn (Qvarsell, Hällström \& Wallin, 2015)

Ett annat aktuellt seminarium som jag engagerar mig i som pensionerad professor i pedagogik är Abduktionsseminariet, där Susanne Andersson tog initiativ till en verksamhet som hon tycker behövs i det pedagogiska livet på institutionen. Här engagerar sig flera av mina tidigare doktorander, numera doktorer och universitetslektorer: Margareta Aspán, Jutta Balldin, Birgitta Odelfors, och därtill Susanne Andersson, Arvid Löfberg och jag. Det har av flera skäl blivit både intressant och relevant att återuppleva och praktisera det abduktiva sätter att relatera teori till data. 
Alltjämt är en tidig källa till detta metodiska förhållningssätt en liten skrift som kom ut i Holland i början av 1970-talet (Fann, 1970). Ett samhällsrelaterat projekt som jag ledde under ett antal år på 1990-talet var FOLK-projektet som med pedagogiskt edukologisk ansats studerade barns (och elevers) möjligheter att medverka i och påverka sin skola och sin värld utanför skolan. De olika delprojekten i FOLK knyts samman genom ett abduktivt arbetssätt (Qvarsell, 1997). Exempel på FOLK-texter finns i litteraturförteckningen: Qvarsell, Dovelius och Eriksson (1995) och Hernwall (1996).

\section{Samarbeten och fortsatt intresse för seminarier}

Det inslag av inflytande och demokrati i pedagogisk verksamhet som jag finner engagerande och viktigt att ägna mig åt även som emerita i pedagogik finns också i ett samarbete med två emeriterade professorer i pedagogik vid Linnéuniversitetet (tidigare Växjö universitet) - Gunilla Härnsten och Lars Holmstrand. Vi kallar oss SPARC, som står för Swedish Participatory Action Research Community, en gemenskap som omfattar flera tidigare och alltjämt verksamma forskare i olika delar av Sverige och folkbildare i landet.

Inom SPARC ges seminarier och kurser om delaktighet och demokrati i samhällsrelaterad forskning. Samarbete mellan universitet och folkbildning betonas. Ett samlat resultat av sådan verksamhet finns i författarpseudonymen och -kollektivet Smilla Parcs bok Tolv russin (2015), som finns listad i litteraturförteckningen. Själva idén med SPARC - att bedriva forskning och utvecklingsarbete i samverkan med omvärlden och att göra det genom deltagande aktionsforskning - kan komma att resultera i förnyelse av pedagogiken som både praktik och vetenskap, på flera vetenskapliga institutioner och inom flera folkbildningsverksamheter.

Annat samarbete under åren som lärare och professor i pedagogik vid Stockholms universitet som jag uppskattat har varit några vikariat vid Linköpings universitet, under ordinarie innehavares tjänstledighet. Det har då varit temat Kommunikation som varit aktuellt, delvis också temat Barn som när det startade kom att adopteras av temat Kommunikation. Samarbete med temaforskare finns dokumenterat i Johannesson och Qvarsell (1995). I Göteborg finns också en livaktig barnforskning genom Ingrid Pramling Samuelsson och hennes grupp som jag lärt känna genom medverkan i seminarier och genom sakkunniggranskning av ansökningar av olika slag. Exempel på samskrivande med forskare i Göteborg finns i litteraturlistan (Doverborg, Pramling \& Qvarsell, 1987 och Klerfelt \& Qvarsell, 2012).

Mitt tidigt utvecklade intresse för språk och kommunikation, knutet till barns villkor, kunde jag under många år fortsätta i kontakter med barnspråksforskaren professor Ragnhild Söderbergh som en period verkade $i$ Lund men samtidigt intresserade sig för forskning $\mathrm{i}$ andra delar av landet. Ragnhild medverkade i mitt Kulturpedagogiska seminarium, där vi fick tillfälle att diskutera olika inlägg av hennes hand (t. ex. Söderbergh, 2009). 
Min medverkan i Högskoleverkets utvärdering av landets pedagogikutbildningar, särskilt forskarutbildningarna, åren 2003-2005 och den utvärdering jag gjorde av en barninriktning vid Göteborgs universitetslärarutbildning (Qvarsell, 2008) har också bidragit till min insikt i andra utbildningar inom landet, vilka varit till nytta och glädje både för mig personligen och förhoppningsvis för de utbildningar som granskats.

\section{LITE FRAMÅTSYN}

Jag vill gärna avsluta den här betraktelsen med att försöka se framåt vad gäller pedagogiken som vetenskap. Häri ingår också problemet att relatera till andra kulturvetenskapliga discipliner, inom humaniora och samhällsvetenskap. Det kan ske genom bruket av semiotik och pragmatism av Charles Peirces (t.ex. 1990) märke. Den engagerande och positiva framtidssyn som den semiotiske pragmatisten och filosofen Richard Rorty (2003) uttrycker i sin bok Hopp $i$ stället för kunskap borde kunna bidra till en sådan framtidsvision, gärna tillsammans med den text av Pierre Rosanvallon (2017) som jag rätt sent kom i kontakt med, en diskussion som visar möjligheter - Ett sambälle av jämlikar. Rosanvallon är en fransk historiker som tagit sig an demokratins historia och problematik som samhällsfenomen vilket är intressant för en samhällspedagogiskt inriktad version av den pedagogiska vetenskapen, med konsekvenser för olika områden av praktik, inte enbart utbildning eller undervisning.

Det kan kanske hävdas att vetenskapen måste vara opolitisk, vilket ofta innebär att inte ta ställning $i$ samhällsfrågor, men jag sätter ett frågetecken för det slaget av värderingsfrihet för pedagogikens del. I framtagandet av innehållet i den samhälleliga pedagogiskt och edukologiskt intressanta världen runt barn och vuxna kan moralfilosofen Ian Hackings (2000) kritiska analys av den sociala konstruktionismen vara till viss vägledning. Hackings varning mot alltför svepande generaliseringar och benämningar för det som samhällsvetare kan avse med "sociala konstruktioner" är tänkvärda och kan leda till utvecklandet av andra begrepp, mera lämpade för det kulturvetenskapliga företaget att förstå mänsklig utveckling och förändring $\mathrm{i}$ relation till omgivande kulturella villkor.

\section{REFERENSER}

Dahlström, K. \& Qvarsell, B. (2008). Globträdet som barnkulturell arena - historik och framtidstankar. I A. Banér (Red.). Barn(s)kultur-nytta eller nöje? Om barn, estetik och pedagogik (s. 93-109). Stockholm: Centrum för Barnkulturforskning, Stockholms universitet, Skriftserien, nr 40. 
Doverborg, E., Pramling I. \& Qvarsell, B. (1987). Inlärning och utveckling. Barnet, förskolan och skolan. Stockholm: Utbildningsförlaget.

Fann, K. T. (1970). Peirce's theory of abduction. Haag: Martinus Nijhoff.

Fisher, J. E. (1996). The domain of educology. International Journal of Educology, 1(1).

Författarkollektivet Smilla Parc (Esseveld, J., Holmstrand, L., Härnsten, G. \& Qvarsell, B.) (Red.) (2015). Ett dussin russin! Tolv texter om deltagarbaserade verksambeter i utbildning och forskning. Stockholm: Runö utbildnings- och utvecklingscentrum \& SPARC - Swedish Participatory Action Research Community.

Gibson, E. (2003). The world is so full of a number of things: On specification and perceptual learning. Ecological Psychology, 15(4), 283-287.

Gibson, J. J. (1979). The ecological approach to visual perception. Boston: Houghton.

Gustavsson, A.(2000). De humanvetenskapliga traditionerna. Texter om forskningsmetod. Nr 5. Stockholm: Stockholms universitet, Pedagogiska institutionen.

Gustavsson, A., Qvarsell, B., Aspán, M. Westanmo, I. \& Bickham, N. (Red.) (2003). 1953 - 2003. Femtioårsskrift för Pedagogiska institutionen vid Stockholms universitet.

Hacking, I. (2000). Social konstruktion av vad? Stockholm: Thales.

Hernwall, P. (1996). Barns perspektiv och skolans informationsteknik- hur datorer och digital informationsteknik kan bli redskap för barns studier av närsambället. FOLK-rapport $\mathrm{nr} 2$. Stockholm: Stockholms universitet, Pedagogiska institutionen.

Johannesson, L. \& Qvarsell, B. (Red.) (1995). Den olydiga boken. Om lättläst-bokens kommunikativa rum. Tema Kommunikations SIC-serie, nr 37. Linköping: Linköpings universitet.

Klerfelt, A. \& Qvarsell, B. (Red.) (2012). Kultur, estetik och barns rätt i pedagogiken. Malmö: Gleerups.

Korczak, J. (1929/1988) Barnets rätt till respekt. Stockholm: Natur och Kultur.

Löfberg, A., Holmberg, I., Dovelius, J. \& Bickham, N. (Red.) (1993). 1953-1993. Fyrtioårsskrift för Pedagogiska institutionen vid Stockholms universitet.

Montgomery, H. \& Qvarsell, B. (Red.) (2001). Perspektiv och förståelse. - Att kunna se från olika håll. Stockholm: Carlsson Bokförlag.

Peirce, C. S. (1990). Pragmatism och kosmologi. Göteborg: Daidalos.

Qvarsell, B. (1966). Subjek.tiv säkerhet i prediktivt beteende. Studier över inlärning av lagbundna samband (Licentiatavhandling). Stockholms universitet. 


\section{BIRGITTA QVARSELL}

Qvarsell, B. (1976). Utvecklingspsykologi och pedagogik. Begreppsdiskussioner och problemidentifieringar (Doktorsavhandling). Stockholms universitet.

Qvarsell, B. (1996). Pedagogisk etnografi för praktiken - en diskussion om förändringsfokuserad pedagogisk forskning. Texter om forskningsmetod, $\mathrm{nr} 2$. Stockholm: Stockholms universitet, Pedagogiska institutionen.

Qvarsell, B. (1997). Forskning i utvecklingsarbete - exemplet FOLK. FOLK-rapport nr 3. Stockholm: Stockholms universitet, Pedagogiska institutionen.

Qvarsell, B. (2000) Children's use of media as transformed experience.

Educological and psychological dimensions. I B. van den Bergh \& J. Van den Bulck (Red.). Children and media: Multidisciplinary approaches. Leuven, Belgium: Garant.

Qvarsell, B. (2003). Mitt sextiotal med psykologin och Psykologen - i olika dimensioner och sammanhang. I L-G. Nilsson (Red.). Psykologiska Institutionen: En jubileumsbok. Stockholm: Stockholms universitet, Psykologiska institutionen.

Qvarsell, B. (2007). Möten under Globträdet. Internationellt kulturarbete med barn. Utvecklingspsykologiska seminariets skriftserie, $\mathrm{nr}$ 74. Stockholm: Stockholms universitet, Pedagogiska institutionen.

Qvarsell, B. (2008) Kultur och språk, för tidigare åldrar - en inriktning inom lärarutbildningen vid Göteborgs universitet (UFL-rapport 2008:03). Göteborg: Göteborgs universitet, Utbildnings- och forskningsnämnden för lärarutbildning.

Qvarsell, B., Dovelius, J. \& Eriksson, J. (1995). Att forska och lära i närsambället. Nya läromönster - Nya arenor? FOLK-rapport nr 1. Stockholm: Stockholms universitet, Pedagogiska institutionen.

Qvarsell, B., Hällström, C. \& Wallin, A. (Red.) (2015). Den problematiska etiken - om barnsyn i forskning och praktik. Göteborg: Daidalos.

Rorty, R. (2003). Hopp i stället för kunskap. Tre föreläsningar om pragmatism. Göteborg: Daidalos.

Rosanvallon, P. (2017). Ett sambälle av jämlikar. Hägersten: Tankekraft förlag.

Söderbergh, R. (2009). Läsa, skriva, tala - barnet erövrar språket. Malmö Gleerups. 